\title{
The Integration of Media literacy education into Ideology and morality education at China's High Schools
}

\author{
Haoyu Wang \\ Education Department \\ Beijing No.27 High School \\ Beijing, China
}

\begin{abstract}
The development of the society has come to the era of media. The media message is increasingly important in public life, with the mediated culture penetrating every corner of the corner of the society. The ubiquity of the media message makes the students in growth confused when make choices. Meanwhile, the value and behavior of students also have changed. The courses of ideology and morality are main platforms for the education of ideology and morality. Therefore, the integration of it and media literacy education is imperative. This essay makes a brief introduction of some relevant concepts and the development history of media literacy education, and tries to illustrate the necessity and feasibility of the very integration, and concludes some suggestions and ideas about the development of media literacy education in the education of ideology and morality.
\end{abstract}

Keywords-secondary education; ideology and morality education; media literacy education; integration; teaching strategies

\section{INTRODUCTION}

Nowadays, human beings are in an era of Big Data with enormous amount of media messages around people's daily life. Therefore, the media information has become an important element affecting the quality of people's life, and the formation of juvenile's worldview, value and life philosophy. To adapt to the development and the demand of the new era, everyone needs to be equipped with fine media literacy. Because of the nature and objective of the ideology and morality education, it is imperative and feasible to integrate media literacy education into the course of ideology and morality.

Starting from the middle school, ideology and morality education in the reform of New Curriculums, by comparing the researches and practices of the media literacy education from abroad, this essay tries to illustrate the feasibility and necessity of the integration of Media literacy education into the courses of ideology and morality from various dimensions such as course standards, textbook, teaching contents, and pedagogical methodologies, with the hope to work out some implementation strategies.

\section{MEDIA LITERACY EDUCATION}

\section{A. Media and Media Literacy Education}

1) Media. Media is the intermediate agency or channel connecting the deliver and the respondent. It is generic term depicting all the media technologies including traditional media such as television, film, newspaper, broadcast, and magazines, and new communication media such as the Internet and mobile phone [1].

2) Literacy. The term of literacy refers to the education background and living skills of an individual. It is usually illustrated as the basic and necessary capacities to adapt to the social life [2].

3) Media Literacy. The term of media literacy refers to the capacity making individuals active media users. People with media literacy are both the recipient of the media content and the producer of the content, who can understand the connotation of social politics, take advantage of the coding to reflect the system, and live in the society with social responsibility [3]. In other words, media literacy is the ability to interpret the media messages in different forms

4) Media Literacy Education. Pu Wei [4], an expert from Journalism and Communication Research Institute, China Academy of Social Sciences, claims that the Media literacy education covers four sections: 1) the basic knowledge about the media and how to use them; 2) learning how to judge the significance and value of the media messages; 3) learning the knowledge and skills of producing and communicating media messages and 4) obtaining the way of exploiting the mass media to make self-improvement. The ideal process of Media literacy education is where the audiences take the usage of the media as a spur of their developments and won't become slaves of the media information and messages because of the very usage. 
B. The Status Quo of Media Literacy Education's Development

1) The Current Situation of Media Literacy Education in $U K$ and USA.

- UK is the cradle of the media literacy education. In 1993 the E.R. Leavis and Denys Thompson publicized their famous works of Culture and Environment: The Training of Critical Awareness. In this book, they first created the term of "Media Literacy". What's more, UK is the first country in this word to integrate the Media literacy education in the curricular system at schools. In 1989, Department of Education and Science introduced the Media literacy education into UK's official education system. In 1997, two thirds of British schools had opened courses of Media Literacy [5].

- The Media literacy education took off a little bit later in America at a slower development speed. The media literacy education had not been recognized by American society until 1970s, however not an independent course in America's national education system. In April 1994, the Media literacy education in America was mainly attached to the education and courses of Art Science in middle and principal schools. However, nowadays, the Media literacy education is acting as an independent course in students' education system in most parts of America[6].

2) The Status of Media literacy education in Hong Kong, Taiwan and China Mainland.

- The media literacy education in Hong Kong, which was named as "Communication Education" started from 1920s. Since 1997, Hong Kong has been developing the reform of Education. With the fast development of Media literacy education, the nonofficial and non-profit education association and foundation has become the core actor and accelerator of the development of Media literacy education. Meanwhile, the Media literacy education has formed its own unique development style in Hong Kong [7].

- As a result of the fast development of Taiwan's media literacy education, on Oct. $24^{\text {th }} 2002$, Taiwan publicized the first White Paper of Media literacy education Polity in Asia, in which it announced the integration of Media literacy education into the compulsory middle and principal school course system, the status of Media literacy education as an education for whole life and for all [8].

- The media literacy education in China Mainland started later with a lower development speed. In June 1997, the Research Institute of Journalism and Communication of China Academy of Social Sciences established the Research Center of Media Communication and Juvenile Development, which marked the first step of China's media literacy education. In 2004, Shanghai Jiao Tong University opened a course named Communication Literacy
Education, making it the first university in China to implement the Media literacy education. In 2005, it launched the Media Literacy and Quality-oriented Education. However, there is no middle or principle school in China having opened the Media literacy education, and meanwhile, few textbooks for the Media literacy education [9].

III. THE INTEGRATION TREND OF IDEOLOGY AND MORALITY EDUCATION AND MEDIA LITERACY EDUCATION

A. The Current Situation of Ideology and morality education in the "Media Storm"

1) The "Media Storm" Striking the Ideology and morality education

- The Ideology and morality education is in a period of transformation; The global information era not only strikes the traditional mainstream culture but also brings about deep impacts on the Ideology and morality education. The course of Ideology and Morality is a significant component of human being's culture from any standpoints. It undertakes the duties of shaping individuals' personalities, inheriting the national culture and improving the culture tastes of people.

- New Objectives of the Course; The new ideology and morality education has put forwarded some requirements in the realm of Media Literacy. For example, in The Academic Benchmark for the Ideology and Morality Course in Compulsory Education System the Competency Objective asks the students to "learn the methodologies of collecting, handling and exploiting information so that to improve the media literacy and adapt to the Information Society positively" [10]. The Competency Objective of Academic Benchmark for Ideology and Morality Courses at Senior High Schools (Experimental) also requires students to "cultivate and adopt various ways especially the modern information technologies, and the ability of collecting and filtering the social information" [11].

- New Curriculum Content; Although there are different versions of Ideology and Morality textbooks, most of them has covered content about Media literacy education. For Example, the third section of "People, Nation and Society" in the Ideology and Morality curriculum's textbook in junior high schools claims that "(student should) take advantage of media such as the Internet rationally, and preliminarily cultivate the ability of positive media critics, and exploit the modern media to participate in the public social life reasonably" [12]. In the compulsory section of "Culture Life" in senior high school's Ideology and Morality curriculum, it asks the students to "list out the main ways of modern culture communication, and evaluate their characteristics respectively; and to understand the progress and evolution of communication technologies, and the deep impacts of 
the education and learning's transformation on the culture inheritance"[13].

\section{2) The High School Students Growing up in the Media} Storm.

- The modern teenagers are impacted by the diversified culture, which is brought about by the development of market-oriented economy and the media since they were born. Both the media and traditional teachers are the channels for them to know the world and acquire knowledge. However, the juveniles are in a life period with no coherent, steady and mature mind-set to differentiate and criticize the media message. They are susceptible to the negative impacts of media, and can be easily addicted to the visual world to escape from the reality.

- First of all, the information content with the style of "Amusing to Death" is interrupting the media environment. The diversified information in different forms of media is deeply attracting the attentions of juveniles by various forms of sensory stimuli. However, these messages are usually lack of strict logics and flat narratives, and blended with enormous amount of harmful information, which will impact the behaviors of teenagers in future subtly. Second, the consumerism is contributing to the increase of juveniles' material desire. Operated under market logic, the mass media now is trying to profit by exploiting those teenagers aspiring for fashion blindly and keeping up with Joneses, by which to maximize their earnings in the market. The juveniles nowadays are tempted and stimulated by different media. They are going after the material consumption fanatically to satisfy their desires with no awareness of the consumerism trend. And the last but not the least, the culture globalization is striking the inheritance of traditional culture. The globalization of the world not only brings about lot of development opportunities but also has disseminated the diversified culture and vast information all over the world. The introduction of the foreign culture will strike the traditional Chinese national culture without any doubts. The foreign culture will inevitably bring along some different culture value judgment and lifestyles, which will erode the status of native culture value. It is very difficult for those teenagers with great curiosity to resist the temptation from the diversified culture, which will lead to a threat for the development and inheritance of Chinese traditional culture.

B. The Necessity and Feasibility of the Integration between Ideology and morality education and Media literacy education

1) An Inevitable Integration for the Development of Ideology and morality education.

- An integration continuing the inheritance and opening up the future; The Ideology and morality education covers content about the education of patriotism, collectivism, and socialism, and the education about idea, ethics, disciplines, legal institution, national security and unity[14]. With the development of society, teachers nowadays have more teaching media choices than the blackboard in the past. After the implementation of the Course-reform, the resource distribution of the Ideology and Morality Curriculum attaches much greater importance to the perspective of practice of the Ideology and morality education, and provide students with more accesses to the matters of ideology and morality in different realms such as society, daily life and science and technology. It is necessary to take the information from different media such as news report, films, TV programs, and the Internet to prove the knowledge in the textbooks when conducting the Ideology and morality education in the Information Era. The filtering, judgment and critique of students and teachers on the media information is an embodiment of the Media literacy education in the process of employing the media messages.

- An integration corresponding to the requirement of this era; tracing back the development of the Ideology and Morality Curriculum, the course needs to change to adapt to the requirements of different eras. In the era of media, it is a duty of the Ideology and morality education to help students to keep ability of reflecting ad criticizing when using the media messages. With the development of in-depth Course-reform, the media information is integrated in the textbook of Ideology and Morality to enhance the connection between the course and the reality, which has helped the students not only to improve the practice ability but also to enhance their media literacy. Meanwhile, the media culture has provided students with both the information, and the value and worldview behind the messages. The Ideology and morality education, corresponding to the call of the duty in this era, should not only be an assistant for students to filter the complicated media messages, but also inculcate them the methodologies to direct them to illustrate the media information in a right way, which integrates Media literacy education into the Ideology and morality education.

2) The Feasibility of the Integration by the Reform of the Ideology and morality education.

- The Ideology and Morality Curriculum needs to include the Media literacy education. The inculcation of Ideology and Morality Curriculum needs media messages in diversified forms to act as a proof evidence for the knowledge in the textbooks. It is also necessary to take advantage of the Ideology and morality education to help students resist the harmful impacts by media culture such as metal vulgarness and utilitarianism and to equip them with critical thoughts and ideas.

- The Ideology and Morality Literacy has covered the Media Literacy. The Media Literacy is a competency of collecting, analyzing and employing media messages, which can be acquired by students through 
the learning of media theories and analysis about media. The Ideology and morality education in the Course-reform asks students to "learn the methodologies of collecting, handling and exploiting information so that to improve the media literacy and adapt to the Information Society positively" and "cultivate and adopt various ways especially the modern information technologies, and the ability of collecting and filtering the social information" [15]. The Media literacy education is consistent to the objectives and requirements of the Ideology and morality education in the high schools, is a good example of the embodiment of the goal of the Ideology and morality education.

- The practical activities of Ideology and morality education are platforms for the Media literacy education. It includes comprehensive study in every learning period of the New Curriculum Standard. And the independent, cooperative and explorative learning methods will surely happen in the comprehensive practical activities. The students act as the subjective of the classroom teaching instead of teachers. The teachers play the role as instructors rather than just transmitters. They help to filter, sort out, analyze and summarize the media messages from those students, and to improve the media literacy of students both through practices and the learning of the Ideology and Morality courses [16].

\section{THE CONDITIONS FOR THE INTEGRATION BETWEEN MEDIA LITERACY EDUCATION AND IDEOLOGY AND MORALITY EDUCATION}

A. The Endogenous Framework of the Ideology and Morality Discipline for the Integration

1) The Textbook of the Ideology and Morality is the Main Media of Integration of Media literacy education.

- Currently, it is difficult to some extent to establish an independent curriculum of Media Literacy. However, it is feasible to integrate the knowledge of Media literacy education into the textbooks of Ideology and Morality Courses, and set up specific objectives and list it in the examination scope. The Academic Benchmark for the Ideology and Morality Course in Compulsory Education System (2011) explicitly asks students to "improve media literacy" in the section about the competency objective of the new curriculum standard[17]. To achieve this goal, the textbooks for students also include some knowledge about media literacy. The textbook needs to adapt to the rapid development of media messages in this era, and aims at cultivating students' ability of sifting and criticizing the media messages by some practices and materials closely related to the learning of Ideology and Morality Curriculum. The exploration for the Media literacy education in the textbook of Ideology and Morality Course is also reflected in application of current affairs in the teaching process of Ideology and Morality, which is based on the given situation of the students and the content of the textbook.
- The content of the current textbook is absent of the introduction of Mass Communication Theory and is too less connected to the modern media environment in the teaching process. Meanwhile, the application of media messages is principally acting as a proof evidence of the knowledge in the textbooks, which is far away from the objective of a critical thought that is proposed by the Media literacy education. The Media literacy education attaches importance to the development of critical thoughts, which refers to an ability of independent judgment when confronted with any media messages. The single option pool of proof evidences for the textbook is also weakening the recognizing ability of students. Therefore, it is necessary to expand the horizon and encourage introducing media messages of diversified forms and dimensions, based on the Media literacy education textbooks of western countries and the national context of China when compiling textbooks to integrate the textbook and the education perse.

2) The Teachers of Ideology and Morality Curriculum are the Dominant Force of the Integration of Media literacy education.

- Firstly, reviewing the development history of Media literacy education in western countries, it was those pioneering teachers who initiated the introduction of the Media literacy education in the class teaching. They integrated their knowledge about media and media culture into the teaching process[18].However, nowadays, those young teachers growing for future education are mostly born in 1990s. They were brought up in an environment around with mass media, where there was no systematic Media literacy education because they were bound by the setting of current tertiary education. To speed up the building of Media Literacy Courses in universities and colleges can accelerate the introduction of Media literacy education by teachers in future.

- At the same time, the basic knowledge of Media literacy education is related to theories in the realm of Mass Communications and Media Psychology. The in-service teachers of Ideology and Morality Curriculum know few things about those terminologies that are already commonly seen in the textbook of Media Literacy in western countries. Although they live in an environment of mass media, they are not equipped with abilities of media analysis and media literacy. Hence, it is an effective promotion for the integration between Media literacy education and Ideology and morality education to open up training sessions of Media Literacy for inservice teachers of Ideology and Morality courses.

- Besides, the objective of the Media literacy education is steady, but the content of the very education is keeping updating and expanding with rapid development of media technologies, which requires the teachers of Ideology and Morality courses to employ different pedagogical methodologies flexibly 
according to different teaching content. Meanwhile, the development of multimedia equipment not only has raised the interests of students but also provided the teachers with abundant platforms to present teaching materials in the teaching practices. As a result, the requirements for the teachers when conducting Media literacy education is becoming increasingly higher with more requests for social responsibility, more passion and more energy.

3) The Teaching Practices of Ideology and morality education is the Principal Way of the Integration.

- To exploit the teaching resources reasonably to integrate the Media literacy education; All the media messages such as text materials, audio and video recordings, and resources on the Internet offers large amount of materials for the Ideology and morality education. By employing these teaching resources, the high school students can broaden their horizon and get abundant teaching contents at the same time. Teachers should encourage students to choose materials from different perspectives to enrich the content in the textbooks, and to improve the media literacy by collecting, sorting, analyzing and exploiting the media messages.

- To integrate the Media literacy education in the classroom teaching; In the teaching of Ideology and morality education, it is necessary to employ large amount of materials to prove the content in the curriculum and to achieve the goal. The good deal of media information after filtration offers effective materials for the classroom teachings. By applying the media messages in the education as teaching materials, teachers can inspire the students to enhance their critical mind-set, and cultivate the ability to illustrate media messages correctly. For instance, the teacher can organize the students to make comparisons between different news reports about the same affair and ask them to write down their own understanding with the teacher acting as an instructor, and thereafter request the students reflect, which can stimulate the passion of students, inspire their idea, disseminate knowledge and improve their media literacies.

- The comprehensive learning of Ideology and Morality is a platform for the conduction of the Media literacy education. Comprehensive learning can break up the limitation of disciplines, integrate the knowledge in the textbooks in the social practices and excavate the subject consciousness of students. The teachers should design the teaching activities around a relevant theme or issue, play the role as an instructor, take the student as the kernel subject, encourage the students to think independently, promote them to cooperate during the exploration, present the outcome of comprehensive learning in different forms, lay the foundation on the knowledge about the Ideology and Morality, integrate the Media literacy education into the Ideology and morality education, to promote the improvement of students' Ideology and Morality Literacy and Media Literacy at the same time.

B. The Exogenous Condition for the Integration into the Ideology and Morality Discipline

1) Improve the Social Recognition for the Media literacy education

- With the background of Global Informationization, there are more and more manifest conflicts between the open commodity market and media messages with diversified value. The foreign diversified culture brings about strong strikes on traditional Chinese national culture. The Ideology and morality education is a principal battlefield of the inheritance of national culture and spirit. Therefore, the integration of Media literacy education, the quintessence of Chinese nation and Chinese traditional culture should be recognized by the whole society, and can be achieved through the Ideology and morality education in high school. Media literacy education is not only aiming at teaching students to cope with the media society in the era of Big Data rationally, but also promoting the development and innovation of the quintessence of Chinese nation and Chinese traditional culture.

- The administration departments of schools should be the kernel of the planning and leading the conduction of the different teaching activities. The school culture has great impacts on the formation of students' life values. Therefore, the internal culture orientation of schools is a safeguard for the students to resist to the external diversified culture outside the campus especially the harmful culture. The schools should promote the conduction of the Media literacy education positively, include it in the teaching program, and supervise and evaluate the outcome and implementation of it. They should greatly improve the media literacy of the teachers of Ideology and morality education; encourage them to participate in training sessions of different levels and different categories; support and encourage the teachers of Ideology and Morality Discipline to develop Media literacy education in the teaching progress.

2) To Enhance the Integration of Media literacy education into the Ideology and morality education from the Dimension of Policies

- The new round of Course-reform of China brings about great development opportunity for the schools to establish the Media Literacy Curriculums with consideration about the real situation of students. However, it is difficult to carry it out in reality. Reviewing the development of Media literacy education in foreign countries, all the promotion effort was ever confronted with great obstacles. The key is whether the Media literacy education was introduced in the scope of examinations. If it is not covered by the examination scope, the teachers will not invest their efforts and time to implement the Media literacy education. However, nowadays, UK 
has already explicitly absorbed the "Media Research" into the examination of General Certificate of Secondary Education (GCSE) [19].

- As a result, it is necessary for the relevant governmental sectors to develop a series of compulsory policy documents to normalize the Media literacy education and guarantee its implementation. First of all, the government education sectors should include the Media literacy education into the system of Ideology and morality education, and make it a component of Ideology and morality education; secondly, develop a quality evaluation institution, and add the content about the Media Literacy into the examinations of Ideology and Morality courses to promote the integration of Media literacy education into the Ideology and morality education; lastly, the government education sectors should organize the compilation of textbooks and reference books that fit in the applications and teachings by teachers of Ideology and Morality courses and the real situations of students, and regularly hold training sessions for the teachers to improve their media literacy, and accelerate the recognition of the teachers to the teaching content about Media Literacy.

3) To Establish Research Institutes for Ideology and morality education and Media literacy education

- Given the experiences of other countries, the organizations of Media literacy education can be divided into two categories: 1) those financially supported by government sectors, and 2) voluntarily founded by non-governmental entities[20]. Both of them will conduct media literacy education researches though regular or irregular training sessions or forums through frontline teachers and experts in the realm of Media literacy education, which combines the theories with the practices, and opens up Media Literacy Courses in schools and publicize relevant readings. The establishment of Media literacy education organizations will bridge the gap between government policies, education theories and the teaching in reality, promote the sharing of resources and experiences effectively, and provide platforms for communication.

- Given the national context of China, the nongovernmental organizations is in a weak situation with little influential ability, so that they can only take the role of an assistant in promoting the Media literacy education. The Chinese government sectors are with a characteristic of power concentration. What's more, the Media Literacy is also related to the issues of ideology. Consequently, the research institutes of Ideology and morality education and Media literacy education should be established directly by government sectors or operated by professional organizations that are entrusted by government sectors. The most effective way is that a top-down model dominated by government.

\section{CONCLUSION}

In the Information Era, the media culture has become an important component of people's mental life, and keeps influencing their behaviors and life styles all the time. With this culture background, the discipline of Ideology and Morality is endowed with new connotations in the new era. The time in high school is an important period for formation of individuals' worldview and life value. The discipline of Ideology and Morality should undertake its time and history duty, to shape the personality of students, promote the students' ability of independent critical thinking, and integrate Media literacy education into the Ideology and morality education effectively.

\section{REFERENCES}

[1] Zhang, Jie (2006). The Research Based on Practice of Media Literacy For Senior middle Students. Submitted as the master dissertation to Shandong Normal University, April 18th, 2006

[2] Long, Lifei (2008). On Contents, Principles and Ways of the Media literacy education. Journal of Guangdong Ocean University, 4, 116119.

[3] Mi, Lijuan (2010). Discussing on Research of Science Innotation of Media Literacy. Journal of Chongqing University of Arts and Sciences (Social Science Edition), 3, 138-142.

[4] Pu, Wei(1997). On the Methodology, Content and Significance of the Media Education. Modern Communication, 1, 32

[5] Hu, Lianli \& Wang, Jia-qi (2007). Advancement and Imperfection of Media Literacy Research in Mainland China. Journal of Hebei University (Philosophy and Social Science Edition), 1, 26-32.

[6] Du, Hongmei (2010). The Contents and Enlightenment of Media Literacy of Mother Tongue Curriculum in the United States. Modern Education Technology, 2, 58-61.

[7] Wang, Canfa (2003). The Education of the Media Quality in China Journal of Hunan Mass Media Vocational Technical College, 3, 7073.

[8] Hu, Lianli \& Wang, Jia-qi (2007). Advancement and Imperfection of Media Literacy Research in Mainland China. Journal of Hebei University (Philosophy and Social Science Edition), 1, 26-32.

[9] Zhang, Hongshu (2009). On the Construction Strategy of Media Cultivation in Mainland China. Journal of Jishou University (Social Science Edition), 9, 150-154

[10] Ministry of Education, P.R.C (2011). The Academic Benchmark for the Ideology and Morality Course in Compulsory Education System. Beijing: Beijing Normal University Press.

[11] Development Team for the Academic Benchmark of Ideology and Morality Courses P.R.C(2005). The Academic Benchmark for Ideology and Morality Courses at Senior High Schools (Experimental). Beijing: People's Education Press.

[12] Ministry of Education, P.R.C (2011). The Academic Benchmark for the Ideology and Morality Course in Compulsory Education System. Beijing: Beijing Normal University Press.

[13] Development Team for the Academic Benchmark of Ideology and Morality Courses P.R.C(2005). The Academic Benchmark for Ideology and Morality Courses at Senior High Schools (Experimental). Beijing: People's Education Press.

[14] Zhang, Zhigang (2003). Obstacles for Accepting Ideological Education: Reasons and Ideal State. Journal of Northeast Normal University (Philosophy and Social Science Edition), 3, 140-144.

[15] Hu, Tiangeng(2012). Analysis for the Academic Benchmark and Textbook of the Ideology and Morality Textbook at High Schools. Beijing: Science Press. 
[16] Hu, Tiangeng(2012). Analysis for the Academic Benchmark and Textbook of the Ideology and Morality Textbook at High Schools. Beijing: Science Press.

[17] Ministry of Education, P.R.C (2011). The Academic Benchmark for the Ideology and Morality Course in Compulsory Education System. Beijing: Beijing Normal University Press.

[18] Qiu, Hao (2012). The Choice of Chinese Media literacy education in Digital Age - On the Evolution of Western Media literacy education Paradigm and its Revelation to China. Journal of Educational Science of Hunan Normal University, 7, 103-106

[19] Dang, Fangli (2006). Theoretical Development and Practice of Media Education in Britain in the 20th Century. Journal of Hainan Normal College (Social Science Edition), 3, 144-147.

[20] Xu, Yonggui \& Liang, Qibing(2006). Comparison and Analysis on Media literacy education Research. China Educational Technology \& Equipment, 12, 74-79. 